\title{
Investigation on chemical composition and optimization of essential oil obtainment from waste Pinus taeda L. using hydrodistillation
}

\author{
Sirlei Dias Teixeira ${ }^{1 *}$, Jhonatan Luiz Fiorio ${ }^{1}$, Diego Galvan ${ }^{1}$, Carolina Sefstrom ${ }^{1}$, Priscila \\ Morgana Cogo ${ }^{1}$, Valber Sales Junior ${ }^{1}$, Márcio Barreto Rodrigues ${ }^{1}$, Ana Paula Palaro Klein \\ Hendges $^{1}$, Beatriz Helena L. de Noronha Sales Maia ${ }^{2}$, Thalita Gilda Santos Benghi². \\ ${ }^{1}$ Chemistry Department, Federal Technological University of Paraná (UTFPR), Pato Branco - PR, Brazil. \\ ${ }^{2}$ Chemistry Department, Federal University of Paraná (UFPR), Curitiba - PR, Brazil.
}

\begin{abstract}
The extraction of essential oils obtained by the hydrodistillation of needles/twigs waste of Pinus taeda L. was optimized by applying response surface methodology (RSM), with $2^{4}$ full factorial design, in order to improve oil essential production, and aggregate value to the production chain of pine wood. Through the model it was possible to ascertain the influence of the variables in the average amount of essential oil $(0.1032 \mathrm{~mL})$, being the variables analyzed: biomass - Bm $\left(x_{1}\right)$, extraction time - ET $\left(x_{2}\right)$, Bm:ET $\left(x_{1} x_{2}\right)$ and sample size - SS: drying times - DT $\left(x_{3} x_{4}\right)$. Only linear terms (biomass and extraction time) and your interaction demonstrated significant positive values $(0.0344,0.0206$ and 0.0131). The major components of the essential oil identified by GC-MS were: $\beta$-phellandrene: (30.39 and $22.44 \%$ ), tricyclene (26.14 and 20.46\%), $\beta$-myrcene (14.32 and $11.50 \%$ ), $\beta$-pinene (22.49 and $1.43 \%$ ) and $\alpha$-pinene $(0.25$ and $11.26 \%)$ in the years 2011 and 2012, respectively. Our results show that the essential oil obtained from $P$. taeda represents a way of using some of the waste generated by the timber industry. The process of obtaining doesn't require treatments such as controlled drying or size reduction of the sample, indicating that it can be used in an industrial scale.
\end{abstract}

Keywords: Pinus, byproduct, essential oil, response surface methodology (RSM), mathematical modeling.

\footnotetext{
1*Authors for correspondence: sirlei@utfpr.edu.br
} 


\section{INTRODUCTION}

Essential oils are natural volatile organic complexes that may contain 100 or more compounds. They are characterized by a strong odor, and are responsible for the protection and fragrance of many aromatic plants (Morais et al. 2006; Castro et al. 2004). Essential oils can be synthesized as secondary metabolites by plant parts such as flowers, leaves, fruits, seeds, roots, rhizomes and stems, being stored in secretory cell cavities, channels, epidermal cells or glandular trichomes (Bakkali et al. 2009; Jin et al. 2007).

The components of essential oils may belong to several class of compounds, but terpenes and some other aromatic and aliphatic constituents are the most common, all of them being characterized by a low molecular weight (Castro et al. 2004; Zeng et al. 2012). Chemical compositions and contents of essential oils in plants vary depending on the plant, season, geographical location, harvesting technique, and genotype (Bendaoud et al. 2009; Botrel et al. 2010).

Essential oils are widely used in the industry. Currently, about 3000 essential oils are known, of which 300 are commercially important, being added to food, cosmetics, perfumes, pharmaceuticals, sanitizers and agricultural products. In those products, they act as flavoring, fragrances, fragrance fixatives, antioxidant, antimicrobial, antiparasitic, virucidal, insecticide, and adjuvant in pharmaceutical and oral compositions marketed in their raw or processed form (Bakkali et al. 2009; Jalali-Heravia et al. 2010; Bizzo et al. 2009).

The genus Pinus, family Pinaceae, is the largest known genus of conifers. With 250 species, it occurs naturally in the Northern Hemisphere and has been cultivated in the temperate regions of the Southern Hemisphere. Pines are evergreen, resinous plants that are often woody, arboreal, varying from 3 to $50 \mathrm{~m}$ (Sonibare and Olakunle 2008). Their trunk is straight and cylindrical, their leaves and branches have a cone shaped arrangement, and their leaves are needle-shaped, grouped in fascicles (Morais et al. 2005).

The species introduced in Brazil come mainly from the United States. Among those, Pinus taeda L. stands out for its productivity and wood quality (Morais et al. 2005; Souza et al. 2008). P. taeda L. has high commercial value and is cultivated in the southern region of Brazil (Carvalho et al. 1998). The wood of this tree is used to make paper and timber, but after harvesting the wood, most of the tree, including twigs and needles, is discarded or burned to generate heat energy for its own industry. Obtaining the essential oil (bioproduct) from this pine would represent a way to utilize some of its byproducts (Oliveira et al. 2006; Ustun et al. 2012; Almeida et al. 2010).

Considering the exiguous literature reports about obtention of essential oils from the byproducts of needles/twigs of $P$. taeda and few reports of their characterization and chemical composition, the aim of this work is to optimize the process using steam hydrodistillation of twigs/needles and carrying out the characterization of the volatile compound of the essential oil. In this regard, this work aims to improve the utilization of the industrial byproducts of the chain production of wood from this pine.

\section{MATERIAL AND METHODS}

\section{Plant Materials}

Fresh needles/twigs of $P$. taeda L. were collected, randomly, in April 2011 and April 2012 in same place under the same conditions, in the city of Palmas, southwestern region of the state of Paraná - Brazil, 29 $9^{\circ} 9^{\prime} \mathrm{S}$ and $51^{\circ} 59^{\prime} \mathrm{W}$, at an altitude of $1,115 \mathrm{~m}$. The voucher specimen of the plant $\left(\mathrm{n}^{\circ}\right.$ HPB 371) was prepared and deposited at the herbarium of the Federal Technological University of Paraná (UTFPR). After collection, the samples were transported in hermetic plastic bags to the laboratory and were dried at room temperature.

\section{Experimental Design}

It was employed an experimental design, consisting of 16 experiments with three replications at the central point, with four independent variables: amount of biomass $(\mathrm{Bm})\left(X_{1}\right)$, extraction time (ET) $\left(X_{2}\right)$, sample size (SS) $\left(X_{3}\right)$ and drying time (DT) $\left(X_{4}\right)$, these were transformed into coded variables $\left(x_{1}, x_{2}, x_{3}\right.$ and $\left.x_{4}\right)$, respectively. Dependent variable $\left(Y_{1}\right)$ was the amount of essential oils obtained in $\mathrm{mL}$. The study of the effect of the different factors on the response was carried out using Statistics for Experimenters - Box, Hunter \& Hunter complete factorial design $\left(2^{4}\right)$ (Box et al. 1978). The experiments were performed in a random order to minimize the effect of the uncontrolled variables (Sereshti et al. 2011; Burkert et al. 2004). 
Mathematical Model

The model used is represented below (1):

$$
Y_{1}=\beta_{0}+\sum \beta_{i} x_{i}+\sum \beta_{i j} x_{i} x_{j}+\sum \beta_{i j k} x_{i} x_{j} x_{k}+\varepsilon
$$

where $Y_{I}$ is dependent variable - amount of oil $(\mathrm{mL}), \beta_{0}$ represents the intercept and $\beta_{i}, \beta_{j}$ and $\beta_{k}$ correspond to linear and interaction term effect coefficients, respectively, and $\varepsilon$ is an error term (Teófilo and Ferreira 2006; Safaralie et al. 2010; Alcântara et al. 2010).

\section{Statistical Analysis}

Optimization of conditions, regression coefficients and analysis of variance (ANOVA) were determined by Statistica v.9.0 Software.

\section{Obtaining the Essential Oil}

Essential oil was obtained following experimental design (RSM), from leaves and twigs/needles fresh and/or dried at room temperature and protected from light. The sample sizes (SS) were 2, 3 and 4 $\mathrm{cm}$, (same ratio of leaves and twigs/needles), and first trials of hydrodistillation occurred within 24 hours after collection. New extractions were done with drying times (DT) of the plant material of 48 and 72 hours. The use of this variable is justified based on the sample humidity analysis carried out in three replications $(57.26 \pm 0.28,48.49 \pm 1.38$ and $45.02 \pm 0.63 \%$ for 24,48 and 72 hours of drying, respectively). The others variables were extraction time (ET) varying $1.0,1.5$ and $2.0 \mathrm{~h}$ and the amount of biomass (Bm) 20, 30 and 40 g. Samples were air dried and mixed with $500 \mathrm{~mL}$ of distilled water and the essential oil was obtained by hydrodistillation in a Clevenger type apparatus. Essential oils were extracted from the aqueous phase using ethyl ether (P.A.) and dried over anhydrous sodium sulphate. Essential oil content was determined on a volume to dry weight basis. After extraction, the samples were placed in glass vials with Teflon-sealed caps at $4{ }^{\circ} \mathrm{C}$ in the absence of light and were kept refrigerated prior to the quantitative and qualitative analysis by gas chromatography-flame ionization detection (GC-FID) and gas chromatography-mass spectrometry (GC-MS). Yield was calculated using the relationship between the essential oil volume obtained and the dry plant material mass used in the extraction (Eq. 2) (Lago et al. 2008).

$$
Y_{2}=\left(v_{e o} / m_{d p m}\right) * 100
$$

where $Y_{2}$ is the yield in $\%, v_{e o}$ the essential oil volume obtained $(\mathrm{mL})$ and $m_{d p m}$ the dry plant material mass $(\mathrm{g})$.

\section{Composition of the Essential Oil}

Identification of volatile constituents of essential oil from the needles/twigs of $P$. taeda by hydrodistillation was performed using a gas chromatograph-mass spectrometer model Shimadzu ${ }^{\odot}$ GC-MS QP 2010 Plus, fitted with a Shimadzu AOC-20i auto sampler, and GC-MS solution version 2.0 software (Shimadzu, USA). The GC-MS measurements were performed using a capillary column $\mathrm{Rtx}^{\circledR}{ }^{\circledR}-5 \mathrm{MS}$ (5\% diphenyl $+95 \%$ dimethyl polysiloxane, $30 \mathrm{~m} \times 0.25 \mathrm{~mm}$ i.d. $\times 0.25$ $\mu \mathrm{m}$ film thickness) and carried out using split/splitless injection, with the injector set at 220 ${ }^{\circ} \mathrm{C}$, the column set at $60{ }^{\circ} \mathrm{C}$, with a heating ramp of $3{ }^{\circ} \mathrm{C} / \mathrm{min}$, a final temperature of $240{ }^{\circ} \mathrm{C}$ and the detector set at $250{ }^{\circ} \mathrm{C}$, with injection of $1 \mu \mathrm{L}$ of sample. Helium (He) was used as the carrier gas at $1 \mathrm{~mL} / \mathrm{min}$. GC-MS electron ionization system was set at $70 \mathrm{eV}$. Quantitative analysis was performed using a Hewlett-Packard 5890 gas chromatograph equipped with a flame ionization detector (GCFID) under the same conditions previously described. GC-FID quantification was obtained using chromatograms and was expressed as the mean from three samples of each extracted essential oil. Before the injection, all samples were diluted to ethyl acetate $(20 \mathrm{mg} / \mathrm{mL})$ for the analyses. Retention indices (RI) were determined by injection of hydrocarbon standards and essential oil samples under the same conditions (Budel et al. 2012). The oil compounds were identified by comparison with data from literature (Adams 2007) and the profiles from the mass spectral libraries (Wiley and NIST).

\section{RESULTS AND DISCUSSION}

\section{Studies of the Effects, Factors and their Interactions}

Factor levels were chosen considering the operating limits of the experimental apparatus based on predefined ranges in the literature, considering the conditions of steam hydrodistillation (Ammar et al. 2010). Each independent parameter tested is presented in Table 1, with their respective symbols 
and actual levels, and coded as low level (-1), high level (+1) and center point $(0)$.

Table 1. Level of the un-coded and encoded independent variables used in the experimental design

\begin{tabular}{|c|c|c|c|c|c|c|}
\hline \multirow{2}{*}{\multicolumn{2}{|c|}{ Independent variables }} & \multirow{2}{*}{ Symbol } & \multicolumn{4}{|c|}{ Levels coded } \\
\hline & & & & -1 & 0 & +1 \\
\hline \multirow{4}{*}{\multicolumn{2}{|c|}{$\begin{array}{l}\mathrm{Bm}^{\mathrm{A}}(\mathrm{g}) \\
\mathrm{ET}^{\mathrm{B}}(\mathrm{h})^{\mathrm{C}} \\
\mathrm{SS}^{\mathrm{D}}(\mathrm{cm}) \\
\mathrm{DT}^{\mathrm{E}}(\mathrm{h})\end{array}$}} & \multirow{4}{*}{$\begin{array}{l}X_{1} \\
X_{2} \\
X_{3} \\
X_{4}\end{array}$} & \multicolumn{2}{|r|}{20} & 30 & 40 \\
\hline & & & \multicolumn{2}{|r|}{1.0} & 1.5 & 2.0 \\
\hline & & & \multicolumn{2}{|r|}{2.0} & 3.0 & 4.0 \\
\hline & & & \multicolumn{2}{|r|}{24} & 48 & 72 \\
\hline & Experiments & $x_{1}$ & $x_{2}$ & $x_{3}$ & $x_{4}$ & $\mathrm{Y}_{1}(\mathrm{~mL})^{\mathrm{F}}$ \\
\hline & 1 & -1 & -1 & -1 & -1 & 0.05 \\
\hline & 2 & +1 & -1 & -1 & -1 & 0.10 \\
\hline & 3 & -1 & +1 & -1 & -1 & 0.05 \\
\hline & 4 & +1 & +1 & -1 & -1 & 0.18 \\
\hline & 5 & -1 & -1 & +1 & -1 & 0.10 \\
\hline & 6 & +1 & -1 & +1 & -1 & 0.12 \\
\hline & 7 & -1 & +1 & +1 & -1 & 0.07 \\
\hline & 8 & +1 & +1 & +1 & -1 & 0.20 \\
\hline & 9 & -1 & -1 & -1 & +1 & 0.05 \\
\hline & 10 & +1 & -1 & -1 & +1 & 0.10 \\
\hline & 11 & -1 & +1 & -1 & +1 & 0.10 \\
\hline & 12 & +1 & +1 & -1 & +1 & 0.21 \\
\hline & 13 & -1 & -1 & +1 & +1 & 0.05 \\
\hline & 14 & +1 & -1 & +1 & +1 & 0.10 \\
\hline & 15 & -1 & +1 & +1 & +1 & 0.09 \\
\hline & 16 & +1 & +1 & +1 & +1 & 0.10 \\
\hline & 17 & 0 & 0 & 0 & 0 & 0.10 \\
\hline $\begin{array}{l}\text { Central } \\
\text { Points }\end{array}$ & 18 & 0 & 0 & 0 & 0 & 0.09 \\
\hline Points & 19 & 0 & 0 & 0 & 0 & 0.10 \\
\hline
\end{tabular}

${ }^{\mathrm{A}} \mathrm{Bm}$ : Biomass; ${ }^{\mathrm{B}} \mathrm{ET}$ : Extraction Time; ${ }^{\mathrm{C}}$ Beginning of the extraction time, corresponding to the fall of the first drop of hidrolate; ${ }^{\mathrm{D}}$ SS: Sample Size; ${ }^{\mathrm{E}} \mathrm{DT}$ : Drying Time; ${ }^{\mathrm{F}}$ Amount of oil.

The mathematical statistical model, which represents the response function, is equivalent to Equation (3). In the canonical equation fitted to the experimental data, the dependent variable $Y_{l}$ is the amount of oil $(\mathrm{mL})$, in which significant terms at the $5 \%$ level are shown with an asterisk.

$$
\begin{aligned}
& Y_{l}=0.1032^{*}+0.0344^{*} x_{1}+0.0206^{*} x_{2} \\
& \begin{array}{lll}
( \pm 0.0041) & ( \pm 0.0045) & ( \pm 0.0045)
\end{array} \\
& -0.0006 x_{3}-0.0044 x_{4}+0.0131^{*} x_{1} x_{2} \\
& -0.0081 x_{1} x_{3}-0.0069 x_{1} x_{4}- \\
& 0.0094 x_{2} x_{3} \\
& ( \pm 0.0045) \quad( \pm 0.0045) \\
& +0.0044 x_{2} x_{4}-0.0144^{*} x_{3} x_{4}- \\
& 0.0044 x_{1} x_{2} x_{3}
\end{aligned}
$$

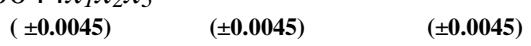

$$
\begin{aligned}
& -0.0106 x_{1} x_{2} x_{4}-0.0044 x_{1} x_{3} x_{4}- \\
& 0.0056 x_{2} x_{3} x_{4} \\
& ( \pm 0.0045) \\
& ( \pm 0.0045) \\
& ( \pm 0.0045)
\end{aligned}
$$

It was found that only $\mathrm{Bm}\left(x_{1}\right)$, ET $\left(x_{2}\right)$, Bm:ET $\left(x_{1} x_{2}\right)$ and SS:DT $\left(x_{3} x_{4}\right)$ were significant at the $5 \%$ level, with $p$ values lower at $4 \%$. All terms significance, except for the SS:DT $\left(x_{3} x_{4}\right)$ had positive coefficients, indicating that they positively influence the amount of essential oil.

Quality of the equation obtained was verified through ANOVA (Table 2), in which the model is significant at the $5 \%$ level $(p=2.5 \%)$, with experimental and adjusted coefficients of determination equal to 96.80 and $85.61 \%$, respectively, and a non-significant regression deviation $(p=5.2 \%)$, confirming the validity of the model for predictive purposes. 
Table 2. Analysis of variance for the response variable

\begin{tabular}{|c|c|c|c|c|c|c|}
\hline & $\begin{array}{l}\text { Degrees of } \\
\text { freedom }(d f)\end{array}$ & $\begin{array}{c}\text { Sum of } \\
\text { Squares (SS) }\end{array}$ & $\begin{array}{c}\text { Mean } \\
\text { Squares (MS) }\end{array}$ & $F$-value & $F_{t a b}$ & $p$-value \\
\hline Model & 14 & 0.03854 & 0.00275 & $8.65^{\mathrm{A}}$ & 5.87 & 0.025 \\
\hline Linear & 4 & 0.02603 & 0.00651 & $20.46^{\mathrm{A}}$ & 6.39 & 0.006 \\
\hline Interaction & 10 & 0.01251 & 0.00125 & $3.93^{\mathrm{B}}$ & 5.96 & 0.100 \\
\hline Residual error & 4 & 0.00128 & 0.00032 & - & - & - \\
\hline Lack-of-fit & 2 & 0.00121 & 0.00060 & $18.10^{\mathrm{B}}$ & 19.00 & 0.052 \\
\hline Pure error & 2 & 0.00007 & 0.00003 & - & - & - \\
\hline Total & 18 & 0.03981 & - & - & - & - \\
\hline$R^{2}=0.9680 / R$ & $=0.8561$ & & & & & \\
\hline
\end{tabular}

Considering that the model was validated, it was used to generate the response surfaces, with the objective to optmize the process. Figure 1 shows the effects of the main variables $\mathrm{Bm}\left(X_{1}\right)$ and $\mathrm{ET}\left(X_{2}\right)$, whereas the other variables, SS $\left(X_{3}\right)$ and DT $\left(X_{4}\right)$, were fixed at their optimum. The boundary region of the response surface demonstrates that there is more essential oil when variables $\mathrm{Bm}\left(X_{l}\right)$ and ET $\left(X_{2}\right)$ are increased.

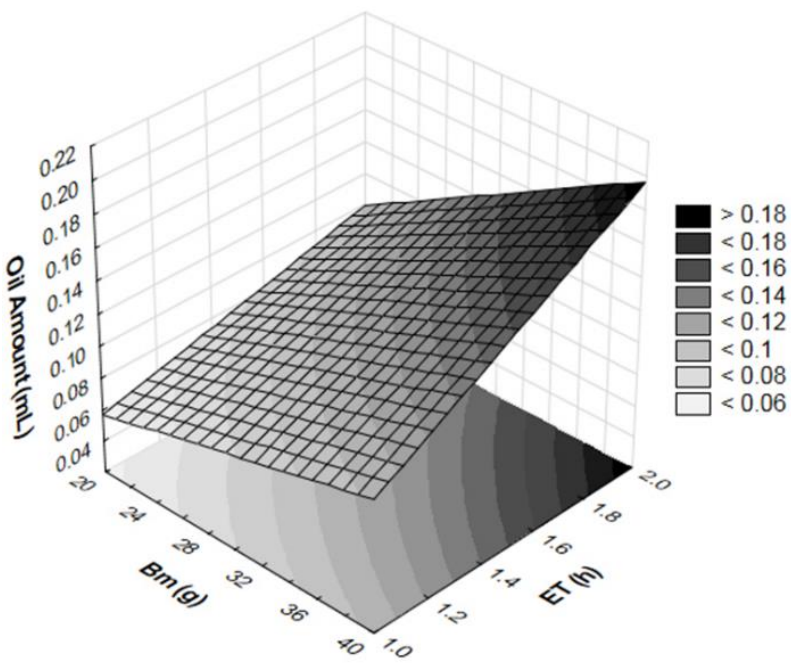

Figure 1. Effects of $\mathrm{Bm}\left(X_{1}\right)$ and ET $\left(X_{2}\right)$ in the amount of essential oil obtained, with SS $\left(X_{3}\right)$ and DT $\left(X_{4}\right)$ fixed at their optimum values.

In Figure 2, in which the surface was generated by the variables SS $\left(X_{3}\right)$ and DT $\left(X_{4}\right)$ setting $\mathrm{Bm}\left(X_{1}\right)$ and ET $\left(X_{2}\right)$ at their values optimum, it can be observed that it is not necessary to reduce the size of the sample when drying the raw material for 24 $\mathrm{h}$, because these procedures do not significantly influence in the amount of essential oil.

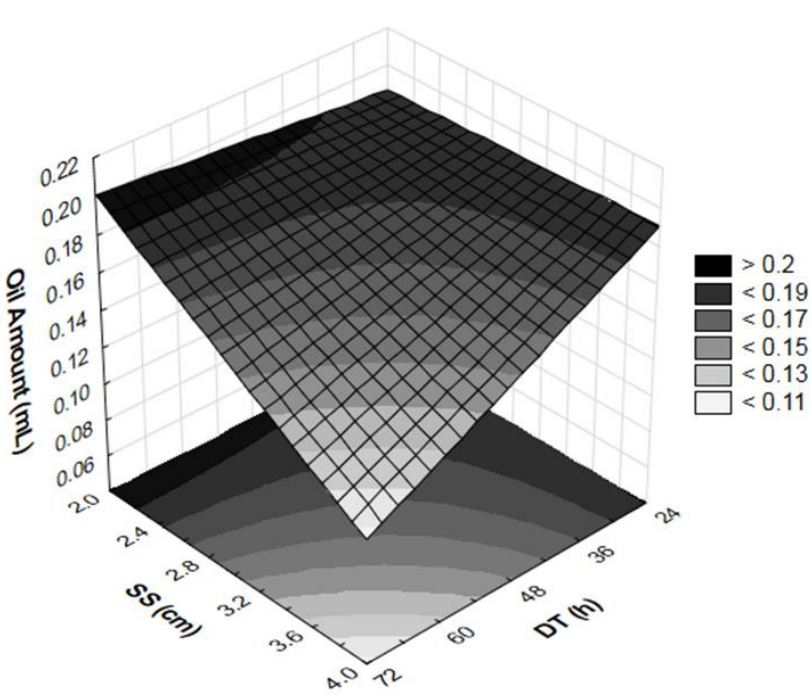

Figure 2. Effects of SS $\left(X_{3}\right)$ and DT $\left(X_{4}\right)$ in the amount of essential oil obtained, with $\operatorname{Bm}\left(X_{1}\right)$ and $\mathrm{ET}\left(X_{2}\right)$ fixed at their optimum values.

\section{Chemical Composition of the Essential Oil}

In order to enable a comparison with the chemical composition of the essential oil obtained in 2011 and 2012, samples were collected in place under the same conditions and their data are shown in Table 3 , together with experimental retention indices (RI), including their percentage peak areas. The characterization of the essential oil from 2011 to 2012 was carried out with the samples that showed higher amount of essential oil determined by RSM (40 g - Bm, $2 \mathrm{~h}-$ ET, $2 \mathrm{~cm}-\mathrm{SS}$ and $72 \mathrm{~h}-\mathrm{DT}$ ). We chose to investigate only the optimal condition for obtaining the essential oil of the same species at different times, since the other experiments may have shown different qualitative and quantitative chemical composition. 
Table 3. Chemical composition of the essential oil of P. taeda L. collected in 2011 and 2012.

\begin{tabular}{|c|c|c|c|c|c|c|}
\hline \multirow{2}{*}{$\mathrm{N}^{\circ}$} & \multirow{2}{*}{ Components } & \multicolumn{2}{|c|}{ (\%) Composition } & \multicolumn{2}{|c|}{$\mathrm{RI}^{\mathrm{A}}$} & \multirow[t]{2}{*}{$\mathrm{RI}^{\mathrm{B}}$} \\
\hline & & 2011 & 2012 & 2011 & 2012 & \\
\hline 1 & Tricyclene & 26.14 & 20.46 & 926 & 928 & 926 \\
\hline 2 & $\alpha$-Pinene & 0.25 & 11.26 & 939 & 943 & 939 \\
\hline 3 & Camphene & 0.91 & - & 953 & - & 954 \\
\hline 4 & Sabinene & 0.04 & - & 976 & - & 975 \\
\hline 5 & $\beta$-Pinene & 22.49 & 1.43 & 980 & 979 & 979 \\
\hline 6 & $\beta$-Myrcene & 14.32 & 11.50 & 991 & 992 & 990 \\
\hline 7 & $\delta$-2-Carene & 0.07 & - & 1001 & - & 1002 \\
\hline 8 & $\beta$-Phellandrene & 30.39 & 22.44 & 1031 & 1030 & 1029 \\
\hline 9 & $\gamma$-Terpinene & 0.05 & - & 1062 & - & 1059 \\
\hline 10 & $p$-Mentha-2,4(8)-diene & 0.55 & - & 1086 & - & 1088 \\
\hline 11 & Linalool & 0.04 & - & 1098 & - & 1096 \\
\hline 12 & Exo-Fenchol & 0.04 & - & 1117 & - & 1121 \\
\hline 13 & $\gamma$-Terpineol & 1.04 & - & 1189 & - & 1199 \\
\hline 14 & Linalool acetate & - & 2.14 & - & 1248 & 1257 \\
\hline 15 & Bornyl acetate & 0.11 & 0.37 & 1285 & - & 1288 \\
\hline 16 & $\alpha$-Terpinyl acetate & - & 0.32 & - & 1346 & 1349 \\
\hline 17 & $\gamma$-Himachalene & - & 0.50 & - & 1484 & 1482 \\
\hline 18 & Germacrene A & 0.06 & - & 1503 & - & 1509 \\
\hline 19 & $\gamma$-Cadinene & - & 0.74 & - & 1507 & 1513 \\
\hline 20 & Zonarene & - & 1.50 & - & 1539 & 1529 \\
\hline 21 & Spathulenol & 0.96 & 3.24 & 1580 & 1589 & 1578 \\
\hline 22 & epi- $\alpha$-Cadinol & - & 2.13 & - & 1647 & 1640 \\
\hline 23 & epi- $\alpha$-Muurolol & - & 4.22 & - & 1649 & 1642 \\
\hline 24 & $\alpha$-Muurolol & - & 2.57 & - & 1651 & 1646 \\
\hline 25 & $\alpha$-Cadinol & 1.02 & 5.08 & 1658 & 1660 & 1654 \\
\hline 26 & Manool & 0.18 & - & 2056 & - & 2057 \\
\hline 27 & Docos-1-ene & - & 0.10 & - & 2176 & 2189 \\
\hline \multirow[t]{13}{*}{28} & $n$-Docosane & - & 0.21 & - & 2198 & 2200 \\
\hline & Monoterpenes & & & & & \\
\hline & Hydrocarbons & 95.21 & 67.09 & & & \\
\hline & Oxygenated & 1.23 & 2.83 & & & \\
\hline & Sesquiterpenes & & & & & \\
\hline & Hydrocarbons & 0.06 & 2.74 & & & \\
\hline & Oxygenated & 1.98 & 17.24 & & & \\
\hline & Diterpenes & & & & & \\
\hline & Oxygenated & 0.18 & - & & & \\
\hline & Other & - & 0.31 & & & \\
\hline & Identified & 98.66 & 90.21 & & & \\
\hline & Not identified & 1.34 & 9.79 & & & \\
\hline & TOTAL & 100 & 100 & & & \\
\hline
\end{tabular}

Essential oil yield $\left(Y_{2}\right)$ obtained from the needles and twigs of $P$. taeda varied between $0.25-0.53 \%$ (results of 2011 and 2012). Content of essential oil, expressed in absolute value, taking into account the experimental design performed in 2011, consisting of 19 trials, with four independent variables (amount of biomass, extraction time, sample size and drying time), varying between $0.05-0.21 \mathrm{~mL}$.
Essential oils from 2011 and 2012 showed 28 components. In 2011 were identified 18 components which represent $98.66 \%$ of the total, and in 2012, 18 components were identified, representing $90.21 \%$. However, $1.34 \%$ and $9.79 \%$ of the total oil remained unidentified in 2011 and 2012, respectively (Table 3). The non-identified compounds have also revealed typical mass spectra 
of hydrocarbons monoterpenes with molecular ions in $\mathrm{m} / \mathrm{z}$ 136; hydrocarbons sesquiterpenes with molecular ions in $\mathrm{m} / \mathrm{z}$ 204; oxygenated sesquiterpenes with molecular ions in $\mathrm{m} / z 218,220$ and 236.

These values are consistent with those reported in previous studies conducted with other species of Pinus, with yields ranging from 0.02 to $2.33 \%$ (w/w or v/w) (Sonibare and Olakunle 2008; Dob et al. 2005; Macchioni et al. 2003; Amri et al. 2012; Rezzi et al. 2001; Kurose et al. 2007; Abi-Ayad et al. 2011), the amount of compounds detected in the order of 22 to 100 (Sonibare and Olakunle 2008; Dob et al. 2005; Macchioni et al. 2003; Amri et al. 2012; Rezzi et al. 2001; Kurose et al. 2007; AbiAyad et al. 2011; Stevanovic et al. 2005; Petrakis et al. 2001) and the proportion of compounds identified from 67.0 to $99.1 \%$ (Sonibare and Olakunle 2008; Dob et al. 2005; Macchioni et al. 2003; Amri et al. 2012; Rezzi et al. 2001; Abi-Ayad et al. 2011; Stevanovic et al. 2005; Petrakis et al. 2001).

The chemical composition of the essential oil had a high proportion of monoterpenes $(96.44 \%$ in 2011 and $69.92 \%$ in 2012), due to the high concentration of hydrocarbon monoterpenes (95.21\% in 2011 and $67.09 \%$ in 2012). The $\beta$-phellandrene was the major component, representing $30.39 \%$ (in 2011) and $22.44 \%$ (in 2012), followed by tricyclene (26.14\%), $\beta$-pinene $(22.49 \%)$ and $\beta$-myrcene $(14.32 \%)$ in 2011; and tricyclene $(20.46 \%), \quad \beta$-myrcene $(11.50 \%)$ and $\alpha$-pinene (11.26\%) in 2012. According to Pagula and Baeckström (2006) the main fraction of the essential oils from pine species is monoterpene hydrocarbons ( $\alpha$-pinene, camphene, $\beta$-pinene, $\delta$-3-carene, $\beta$-myrcene, limonene and $\beta$-phellandrene), which is in agreement with published results. Researches with Pinus species show that the main components of the oils are monoterpenes, mainly the hydrocarbon type, composing $60-70 \%$ of the oil, followed by oxygenated monoterpenes, sesquiterpenes oxygenated and hydrocarbons (Amri et al. 2012; Stevanovic et al. 2005; Petrakis et al. 2001). Oxygenated monoterpenes were also detected (1.23\% in 2011 and $2.83 \%$ in 2012) in P. taeda. Other compounds, such as sesquiterpenes (hydrocarbons and oxygenated) and diterpenes are represented in minor quantities $(2.22 \%)$, in the 2011. On the other hand, in analyzes made with the essential oil obtained in 2012, other compounds, such as sesquiterpenes hydrocarbons and oxygenated were represented in considerable amounts (2.74\% and $17.24 \%$, respectively). Some identified compounds have very similar chemical structures ((21) spathulenol; (22) epi- $\alpha$-cadinol; (23) epi- $\alpha$-muurolol; (24) $\alpha$-muurolol and (25) $\alpha$ cadinol), therefore the chromatogram had to be expanded in the region of retention times of those peaks according Figure 3. Sesquiterpenes (hydrocarbons and oxygenated) as $\beta$ caryophyllene, $\alpha$-cadinene, $\gamma$-cadinene, $\quad \gamma$ muurolene, $\alpha$-humulene, $\alpha$-muurolol, $\alpha$-cadinol and caryophyllene oxide, are usually detected in essential oils of pines in low amounts (Pagula and Baeckström 2006). This did not occur with the sample of 2012, $\alpha$-muurolol $(2.57 \%), \alpha$-cadinol (5.08\%), epi- $\alpha$-muurolol (4.22\%) and epi- $\alpha$-cadinol $(2.13 \%)$ were detected.

Differences in the concentration of essential oil constituents can vary according to genetic, physiological and climatic factors, type of soil and extraction technique (Bakkali et al. 2009). MéndezTovar et al. (2016) emphasizes that environmental factors influence the composition of essential oils, and must be taken into account. Another factor to consider is that the essential oil was obtained from residual plant material (twigs and needles) which, after cutting the tree trunk, were deposited on the ground exposed to inclement weather. As reported by Bier et al. (2016) the low concentration of some constituents in the waste may be due to the results for the essential oil of Pinus being obtained from fresh samples and not from agricultural residues from forest soil.

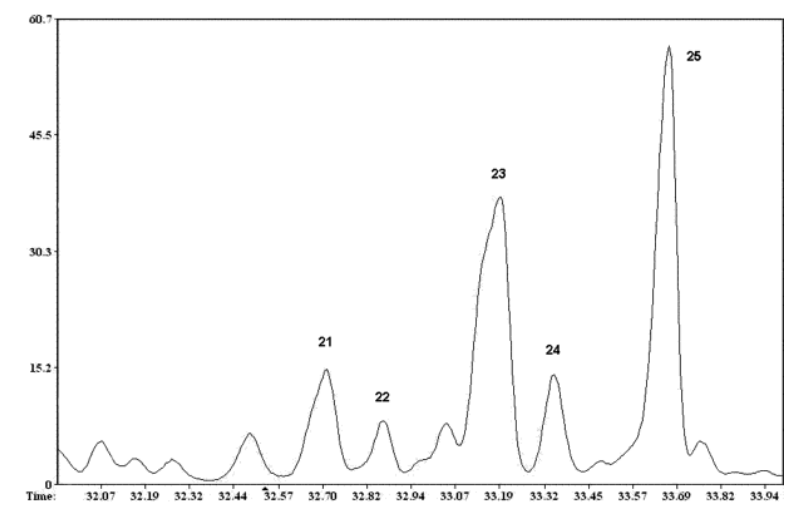

Figure 3. Chromatogram in expanded view of the essential oil from P. taeda L. collected in 2012.

The mass spectra corresponding to each compound in the expanded chromatogram were inserted in the Figure 4 (A-E), where mass spectra corresponding to peaks 21 (spathulenol), 22 (epi- $\alpha$-cadinol), 23 (epi- $\alpha$-muurolol), $24(\alpha$-muurolol $)$ and $25(\alpha$ cadinol ), respectively. 


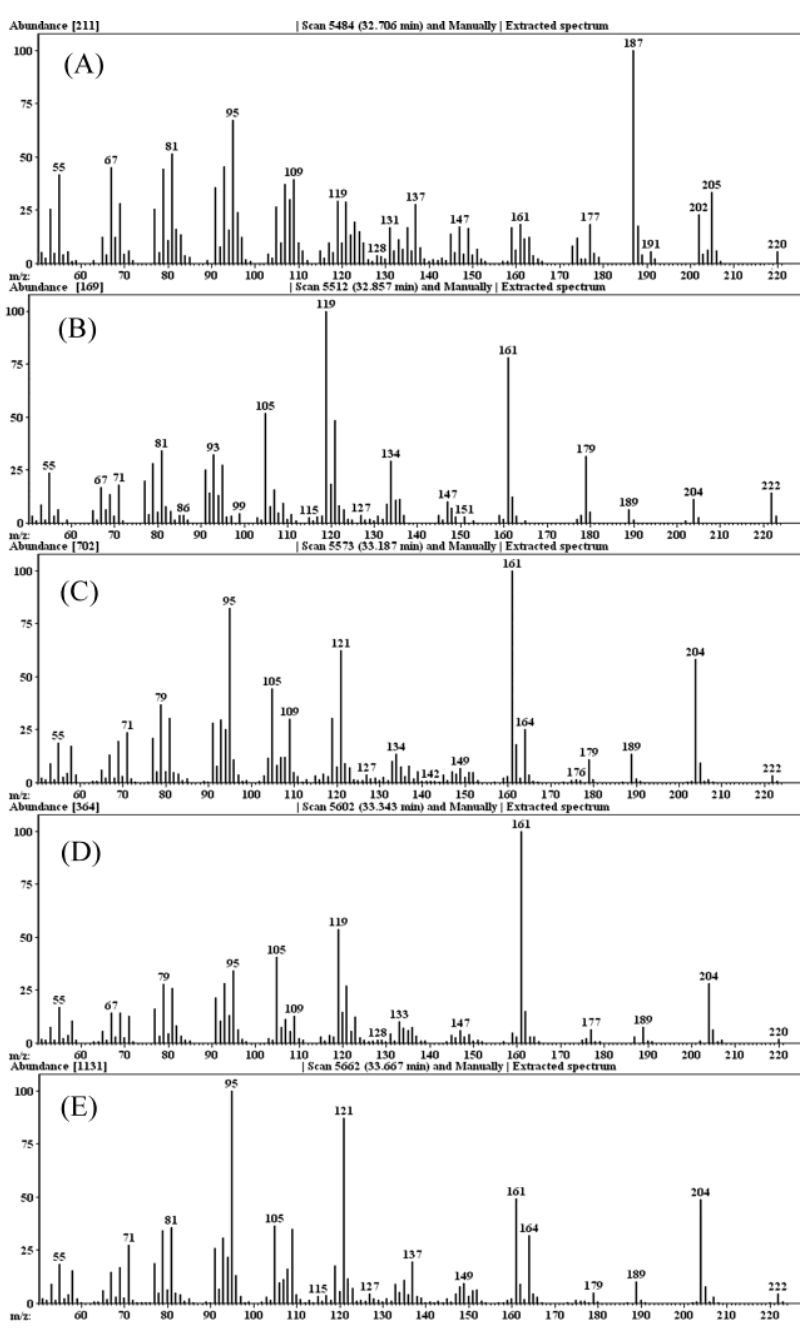

Figure 4. Mass spectrum of the spathulenol (peak 21) (A); epi- $\alpha$-cadinol (peak 22) (B); epi- $\alpha$-muurolol (peak 23) (C); $\alpha$-muurolol (peak 24) (D); $\alpha$-cadinol (peak 25) (E).

Bier et al. (2016) reports studies (forest wastes) of the volatile composition of residues are rare in the literature. The residues of $P$. taeda (needles) and $P$. ellioti (wood shavings) was study for the use as source of terpenoids (limonene, $\alpha$-pinene and $\beta$ pinene) by pressurized liquefied petroleum gas (LPG) extraction, at yields of $2.32 \%$ for the pine needle and $0.6 \%$ for the pine wood shavings, obtaining 0.48 and $0.38 \%$ of limonene; 0.57 and $2.93 \%$ of $\alpha$-pinene; 7.37 and $6.34 \%$ of $\beta$-pinene, respectively. However, the LPG extraction displayed less decomposition or modification of the compounds. Adams et al. (2014), evaluated the essential oil composition from forestry byproducts of P. taeda in mid-April to mid-September 2013. The major components of the oil were $\alpha$-pinene (36.61 to $42.48 \%$ ), $\beta$-pinene (11.96 to $14.70 \%$ ), limonene (1.55 to $4.90 \%)$, terpineol (2.78 to $7.14 \%$ ), and caryophyllene (7.24 to $10.23 \%$ ). The camphene, $\beta$-myrcene, $\beta$-phellandrene and $\beta$ caryophyllene oxide, were not detected in any month. As occurred in the present work with some components. Furthermore, the results demonstrated that the essential oils had antimicrobial activity against four Staphylococcus aureus strains (Adams et al. 2014).

Pagula and Baeckström (2006) analyzed essential oil composition of fresh needles from $P$. taeda grown in Mozambique. In their report, 27 compounds were identified, totalizing $95.0 \%$ of identified compounds at yield of $0.83 \%$ of oil. The major components of the essential oil identified were: tricyclene $(3.8 \%), \alpha$-pinene $(62.3 \%), \beta$ pinene $(7.1 \%)$, limonene $(2.0 \%), \beta$-myrcene $(1.8 \%)$ and $\beta$-phellandrene (3.7\%), respectively. Which is in agreement with published results of Table 3 , with exception of limonene (not detected).

In their research, Kurose et al. (2007) analyzed the chemical composition of essential oil from leaves and cones of eleven species of Pinus, including $P$. taeda. Essential oil of the $P$. taeda had 35 compounds formed mainly by monoterpenes $(98.7 \%)$ and sesquiterpenes $(0.7 \%), \alpha$-pinene being the major component (51.8\%), followed by $p$ mentha-1,5-dien-8-ol, verbenone, (both amounting $4.8 \%)$ and $\beta$-pinene (3.8\%). Tricyclene, $\beta$-myrcene and $\beta$-phellandrene were also present, however, in lower proportions than those obtained in this work, being $0.8,0.3$ and $0.2 \%$, respectively.

In others pine species the composition of oil from needles/twigs/cones of four species (Pinus pinea, $P$. halepensis, $P$. pinaster and $P$. nigra) from Italy (Macchioni et al. 2003), five species (P. brutia, $P$. halepensis, $P$. nigra, $P$. pinea, and $P$. sylvestris) from Turkey (Ustun et al. 2012) and five species ( $P$. attenuata, $P$. heldreichii, $P$. peuce, $P$. pinaster and $P$. radiata) from Greece (Petrakis et al. 2001) were analyzed. With exception of two species from Greece ( $P$. peuce and $P$. pinaster), all the other species presented $\beta$-pinene ( 0.7 to $47.5 \%$ ), $\alpha$-pinene (6.2 to $96.5 \%), \beta$-myrcene $(0.2$ to $42.1 \%)$ and $\beta$ phellandrene $(0.3-7.5 \%$ and traces). Tricyclene $(0.1-0.5 \%$ and traces) was not detected in one specie from Italy $(P$. pinea) and some from Turkey ( $P$. halepensis, $P$. nigra, $P$. pinea, and $P$. sylvestris). The chemical composition of the essential oils of $P$. nigra (Rezzi et al. 2001), P. caribaea (Sonibare and Olakunle 2008), and P. mugo (Stevanovic et al. 2005) have also been previously investigated. $\beta$ - 
pinene was present in all species, amounting 0.5 to $25.1 \%, \beta$-phellandrene from 1.1 to $67.9 \%$ and $\alpha$ pinene from 5.4 to $70.0 \%$. Moreover, tricyclene was detected only in $P$. mugo $(0.4 \%)$ and $\beta$-myrcene in $P$. nigra and $P$. mugo (0.7 to $30.0 \%)$. High concentration of $\beta$-phellandrene in the oil suggests that it might work as a fragrance because of its pleasing aroma (Sonibare and Olakunle 2008). However, further studies are required to determine the applicability, cost, safety and toxicity of these bioproducts.

The composition of the essential oil of $P$. halepensis (Dob et al. 2005) and P. pinea (Amri et al. 2012) showed $\beta$-pinene ( 0.2 and 3.4\%), $\alpha$-pinene (1.2 and $7.7 \%$ ) and $\beta$-myrcene (3.1 and $2.7 \%$ ), respectively. Only $0.36 \%$ of $\beta$-phellandrene was detected in $P$. pinea and not detected in $P$. halepensis, whereas tricyclene was found in both species in traces. AbiAyad et al. (2011) did not detect any of the five main compounds of $P$. taeda in $P$. halepensis.

\section{CONCLUSION}

Twigs and needles are wasted because there is no information on what can be done with them and how to do so. The model allowed us to demonstrate the influence of the variables on the amount of essential oil obtained, showing that the linear factors $\operatorname{Bm}\left(x_{1}\right)$ and ET $\left(x_{2}\right)$ and the binary combination Bm:ET $\left(x_{1} x_{2}\right)$ had a positive effect, whereas SS:DT $\left(x_{3} x_{4}\right)$ had a negative one. We demonstrated, through the RSM methodology, that in order to obtain the essential oil there is no need to decrease the size of the sample or controlled drying. Results indicate a great chemical variability in the essential oil of $P$. taeda L., with high proportion of monoterpenes, while other compounds such as sesquiterpenes and diterpenes are minority. Main constituents of the essential oil obtained in 2011 and 2012 were $\beta$-phellandrene, tricyclene, $a$-pinene, $\beta$-myrcene and $\beta$-pinene.

\section{ACKNOWLEDGEMENTS}

The work was financially supported by DIRPPG/UTFPR - Câmpus Pato Branco/PR. We thank the Chemistry Department, Federal University of Paraná.

\section{REFERENCES}

Abi-Ayad M, Abi-Ayad FZ, Lazzouni HA, Rebiahi SA, Ziani-Cherif C, Bessiere J. Chemical composition and antifungal activity of Aleppo pine essential oil. J Med Plants Res. 2011; 5: 5433-5436.

Adams J, Gibson KE, Martin EM, Almeida G, Ricke SC, Frederick N, Carrier DJ. Characterization and variation of essential oil from Pinus taeda and antimicrobial effects against antibiotic-resistant and susceptible Staphylococcus aureus. Forest Prod. J. 2014; 64: 161-165.

Adams RP. Identification of Essential Oil Components by Gas Chromatography/Mass Spectroscopy. Illinois: Allured Publishing Corporation, 2007, 804 p.

Alcântara JM, Yamaguchi KKL, Veiga Junior VF. Essential oils composition from Aniba and Licaria species and their antioxidant and antiplatelet activities. Quim Nova 2010; 33: 141-145.

Almeida NF, Camargo DT, Arriel DAA, Mori FA. Evaluation of the properties of Pinus patula residues in different storage periods aiming at energy cogeneration. Revista Floresta. 2010; 40: 269-274.

Ammar AH, Zagrouba F, Romdhane M. Optimization of operating conditions of Tunisian myrtle (Myrtus communis L.) essential oil extraction by a hydrodistillation process using a $2^{4}$ complete factorial design. Flavour Fragr J. 2010; 25: 503-507.

Amri I, Gargouri S, Hamrouni L, Hanana M, Fezzani T, Jamoussi B. Chemical composition, phytotoxic and antifungal activities of Pinus pinea essential oil. J Pest Sci. 2012; 85: 199-207.

Bakkali F, Averbeck S, Averbeck D, Idaomar M. Biological effects of essential oils - A review. Food Chem Toxicol. 2009; 46: 446-475.

Bendaoud H, Bouajila J, Rhouma A, Savagnac A, Romdhane M. GC/MS analysis and antimicrobial and antioxidant activities of essential oil of Eucalyptus radiata. J Sci Food Agric. 2009; 89: 1292-1297.

Bier MCJ , Medeiros ABP, Oliveira JS, Côcco LC, Costa JL, Carvalho JC, Soccol CR. Liquefied gas extraction: A new method for the recovery of terpenoids from agroindustrial and forest wastes. J Supercrit. Fluid. 2016; 110: 97-102.

Bizzo HR, Hovell AMC, Rezende CM. Brazilian essential oils: general view, developments and perspectives. Quim Nova. 2009; 32: 588-594.

Botrel PP, Pinto JEBP, Ferraz V, Bertolucci SKV, Figueiredo FC. Content and chemical composition of Hyptis marrubioides essential oil in function of seasons. Acta Sci. Agron. 2010; 32: 533-538.

Box GEP, Hunter WG, Hunter JS. Statistics for Experimenters: An Introduction to Design, Data Analysis and Model Building. New York: John Wiley \& Sons, 1978, $653 \mathrm{p}$.

Budel JM, Duarte MR, Döll-Boscardin PM, Farago PV, Matzenbacher NI, Sartoratto A, Maia BHLNS. Composition of essential oils and secretory structures 
of Baccharis anomala, B. megapotamica and $B$. ochracea. J Essent Oil Res. 2012; 24: 19-24.

Burkert JFM, Maugeri F, Rodrigues MI. Optimization of extracellular lipase production by Geotrichum $s p$. using factorial design. Bioresour Technol. 2004; 91: 77-84.

Carvalho MG, Rumjanek VM, Lopes MJS, Carvalho AG. Diterpenes from Pinus taeda. Phytochem. 1998; 49: 1101-1105.

Castro HG, Oliveira LO, Barbosa LCA, Ferreira FA, Silva DJH, Mosquim PR, Nascimento EA. Content and composition of the essential oil of five accesses of mentrasto. Quim Nova. 2004; 27: 55-57.

Dob T, Berramdane T, Chelgoum C. Chemical composition of essential oil of Pinus halepensis Miller growing in Algeria. C R Chim. 2005; 8: 1939-1945.

Jalali-Heravia M, Parastar H, Sereshti H. Towards obtaining more information from gas chromatography-mass spectrometric data of essential oils: An overview of mean field independent component analysis. J. Chromatogr A. 2010; 1217 : 4850-4861.

Jin P, Wang SW, Gao H, Chen H, Zheng Y, Wang CY. Effect of cultural system and essential oil treatment on antioxidant capacity in raspberries. Food Chem. 2007; 132: 399-405.

Kurose K, Okamura D, Yatagai M. Composition of the essential oils from the leaves of nine Pinus species and the cones of three of Pinus species. Flavour Fragr J. 2007; 22: 10-20.

Lago JHG, Romoff P, Fávero OA. Composition of essential oils from the leaves of six species of the Baccharis genus from "Campos de Altitude" of the Atlantic forest of São Paulo. Quim Nova. 2008; 31: 727-730.

Macchioni F, Cioni PL, Flamini G, Morelli I, Maccioni S, Ansaldi M. Chemical composition of essential oils from needles, branches and cones of Pinus pinea, $P$. halepensis, $P$. pinaster and $P$. nigra from central Italy. Flavour Fragr J. 2003; 18: 139-143.

Méndez-Tovar I, Novak J, Sponza S, Herrero B, Asensio-S-Manzanera MC. Variability in essential oil composition of wild populations of Labiatae species collected in Spain. Ind Crops Prod. 2016; 79: 18-28.

Morais SAL, Nascimento EA, Melo DC. Chemical analysis of Pinus oocarpa wood part I - quantification of macromolecular components and volatile extractives. Rev Árvore. 2005; 29: 461-470.

Morais SM, Catunda Júnior FEA, Silva ARA, Martins Neto JS, Rondina D, Cardoso JHL. Antioxidant activity of essential oils from northeastern brazilian Croton species. Quim Nova. 2006; 29: 907-910.

Oliveira FL, Lima IS, Garcia JN, Florsheim SMB. Propriedades da madeira de Pinus taeda L. em função da idade e da posição radial na tora. Rev Inst Flor. 2006; 18: 59-70.

Pagula FP, Baeckström P. Studies on essential oilbearing plants from Mozambique: Part II. Volatile leaf oil of needles of Pinus elliottii Engelm. and Pinus taeda L. J Essent Oil Res. 2006; 18: 32-34.

Petrakis PV, Tsitsimpikou C, Tzakou O, Couladis M, Vagias C, Roussis V. Needle volatiles from five Pinus species growing in Greece. Flavour Fragr J. 2001; 16: 249-252.

Rezzi S, Bighelli A, Mouillot D, Casanova J. Composition and chemical variability of the needle essential oil of Pinus nigra subsp. laricio from Corsica. Flavour Fragr J. 2001; 16: 379-383.

Safaralie A, Fatemi S, Salimi A. Experimental design on supercritical extraction of essential oil from valerian roots and study of optimal conditions. Food Bioprod Process. 2010; 88: 312-318.

Sereshti H, Izadmanesh Y, Samadi S. Optimized ultrasonic assisted extraction-dispersive liquid-liquid microextraction coupled with gas chromatography for determination of essential oil of Oliveria decumbens Vent. J Chromatogr A. 2011; 1218: 4593-4598.

Sonibare OO, Olakunle K. Chemical composition and antibacterial activity of the essential oil of Pinus caribaea from Nigeria. Afr J Biotechnol. 2008; 7: 2462-2464.

Souza CAM, Sartori DB, Rocha AS, Schneider PR. Artificial form factor of Pinus taeda L. for the region Central-West of Paraná (Brazil). Revista Científica Eletrônica de Engenharia Florestal. 2008; 12: 1-11.

Stevanovic T, Garneau FX, Jean FI, Gagnon H, Vilotic D, Petrovic S, Ruzic N, Pichette A. The essential oil composition of Pinus mugo Turra from Serbia. Flavour Fragr J. 2005; 20: 96-97.

Teófilo RF, Ferreira MC. Chemometrics II: spreadsheets for experimental design calculations, a tutorial. Quim Nova. 2006; 29: 338-350.

Ustun O, Senol FS, Kurkcuoglu M, Orhan IE, Kartal M, Baser KHC. Investigation on chemical composition, anticholinesterase and antioxidant activities of extracts and essential oils of Turkish Pinus species and pycnogenol. Ind Crops Prod. 2012; 38: 115-123.

Zeng WC, Zhang Z, Gao H, Jia LR, He Q. Chemical composition, antioxidant, and antimicrobial activities of essential oil from pine needle (Cedrus deodara). $J$ Food Sci. 2012; 77: C824-C829.

Received: January 24, 2016 Accepted: April 26, 2016 